\title{
EGFR is not amplified in ameloblastoma
}

Victor Costa, DDS, MSc, ${ }^{a}$ Eduardo Rodrigues Fregnani, DDS, PhD, ${ }^{\mathrm{b}}$ Felipe Paiva Fonseca, DDS, PhD, ${ }^{\mathrm{c}}$ Fábio Abreu Alves, DDS, PhD, ${ }^{\mathrm{d}}$ Clóvis Antônio Lopes Pinto, $\mathrm{MD}, \mathrm{PhD},{ }^{\mathrm{e}}$ and Estela Kaminagakura, DDS, $\mathrm{PhD}^{\mathrm{a}}$

Objective. The aim of this study was to investigate alterations in the EGFR gene and its protein expression for a better understanding of the biologic behavior of ameloblastoma.

Study Design. Twenty-five samples of ameloblastoma were selected, and dual-color fluorescence in situ hybridization assay was performed. The results of the assay and immunohistochemistry reaction for EGFR and Ki67 were associated with clinicopathologic features and recurrence.

Results. All analyzed cases presented disomy without any gene polysomy or amplification. With regard to EGFR immunoexpression, 3 cases (12\%) were considered negative, and 22 (88\%) were positive, of which $13(52 \%)$ were weak and 9 (36\%) were strong. All samples presented low positivity for Ki67. There was no association between EGFR expression and clinicopathologic features or recurrence $(P>.05)$. In some cases, EGFR immunoexpression was observed without gene amplification.

Conclusions. Ameloblastoma development, progression, or recurrence does not appear to be related to EGFR amplification or polysomy. (Oral Surg Oral Med Oral Pathol Oral Radiol 2018;125:454-458)

Ameloblastoma is a benign epithelial odontogenic neoplasm that has a tendency to cause local and progressive destruction of bone and soft tissue. This tumor is exclusively found in maxillary bones and occurs mainly between the fourth and fifth decades of life, with no gender predilection. In about $80 \%$ of the cases, the lesions are located in the mandible, with a higher tendency toward the posterior region. ${ }^{1}$

In the 2017 World Health Organization's Classification of Head and Neck Tumors, the classification of ameloblastoma was simplified and narrowed to "ameloblastoma, unicystic and peripheral." Although the adjective "solid/multicystic" has been discarded, its subtype demonstrates aggressive behavior, infiltrating into cancellous bone trabeculae and recurrence rates of $22 \%$; the unicystic subtype is less aggressive and is usually treated as a cystic lesion, with $29 \%$ of recurrence. ${ }^{3,4}$

The epidermal growth factor receptor (EGFR; or ErbB-1 or HER1) is a tyrosine kinase receptor and a member of the ErbB receptor family. Its phosphorylation can activate multiple epithelial mitogenic signaling pathways, such as those of mitogen-activated protein kinases/extracellular signal-regulated kinases (MAPK/ ERK) and phosphoinositide 3-kinase/phosphatase

\footnotetext{
${ }^{\mathrm{a} D e p a r t m e n t ~ o f ~ B i o s c i e n c e s ~ a n d ~ O r a l ~ D i a g n o s i s, ~ I n s t i t u t e ~ o f ~ S c i e n c e ~}$ and Technology, São Paulo State University (Unesp), São José dos Campos, Brazil.

bepartment of Oral Medicine, Sírio-Libanês Hospital, São Paulo, Brazil.

'Department of Oral Surgery and Pathology, School of Dentistry, Universidade Federal de Minas Gerais, Belo Horizonte, Brazil.

${ }^{\mathrm{d} D e p a r t m e n t ~ o f ~ S t o m a t o l o g y, ~ A . C . ~ C a m a r g o ~ C a n c e r ~ C e n t e r, ~ S a ̃ o ~ P a u l o, ~}$ Brazil.

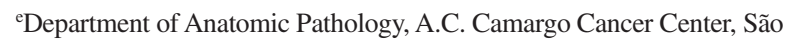
Paulo, Brazil.

Received for publication Nov 11, 2017; returned for revision Feb 10, 2018; accepted for publication Feb 19, 2018.

(C) 2018 Elsevier Inc. All rights reserved.

2212-4403/\$ - see front matter

https://doi.org/10.1016/j.0ooo.2018.02.014
}

and tensin homolog deleted on chromosome 10 (PI3 K/PTEN) ${ }^{5-10}$ The activation of these pathways induces several cellular processes, including proliferation, migration, invasion, transformation, differentiation, angiogenesis, and apoptosis inhibition. ${ }^{8}$ Mutations in genes that belong to the MAPK pathway are reported in about $90 \%$ of ameloblastoma cases ${ }^{11}$ but little is known about the role of EGFR mutations/alterations in the pathogenesis of this neoplasm.

For a better understanding of the pathogenesis and biologic behavior of ameloblastoma, some biologic pathways and their associated genes have been studied. In the literature, the role of EGFR polysomy and amplification is not clear. The aims of this study were therefore to investigate $E G F R$ alteration in ameloblastoma samples, using fluorescence in situ hybridization (FISH) and immunohistochemistry (IHC), and associate the results with the clinicopathologic features and recurrence.

\section{MATERIALS AND METHODS Ameloblastoma samples}

The Research ethics committee of the A.C. Camargo Cancer Center approved this study (Protocol No. 669/ 05). A retrospective study was performed analyzing cases of ameloblastoma admitted for treatment at the Department of Otolaryngology and Head and Neck Surgery during the period 1953 to 2003, with available paraffin blocks and clinical and follow-up information. Twenty-five

\section{Statement of Clinical Relevance}

Ameloblastoma development, progression, or aggressiveness is not related to EGFR alterations. This is the first study using fluorescence in situ hybridization to investigate $E G F R$ gene alterations in a series of ameloblastoma cases. 
cases of ameloblastoma were found to be suitable for analysis. By following the $2017 \mathrm{WHO}$ guidelines, ${ }^{1} 2$ pathologists (ERF and FAA) reviewed the histopathologic results to confirm the diagnoses.

Tissue microarray (TMA) blocks were constructed, as described by Fregnani et al. ${ }^{12}$

\section{Dual-color fluorescence in situ hybridization}

One slide of the TMA block was subjected to FISH analysis, using the ZytoLight Spec EGFR/CEN7 Dual Color Probe (ZytoVision, Bremerhaven, Germany) that contains both the fluorescently labeled EGFR gene and chromosome 7 centromere (CEN7) probes. In brief, the sections were incubated overnight at $56^{\circ} \mathrm{C}$ and then deparaffinized by being washed in xylene, ethanol, and distilled water. After incubation in $0.2 \mathrm{M}$ hydrochloric acid for 20 minutes at room temperature, the sections were heat pretreated in a citrate buffer $(2 \times$ saline-sodium citrate [SSC], pH 6.0) for 1 hour at $80^{\circ} \mathrm{C}$. Next, the sections were digested with pepsin for 8 minutes at room temperature, rinsed in $2 \times \mathrm{SSC}$ for 2 minutes at room temperature, and dehydrated in an increasing ethanol series $(75 \%, 80 \%$, and $100 \%$ ) for 2 minutes each. The EGFR/CEN7 probe mix was applied to the dried slides, and the tissue area was coverslipped and sealed with rubber cement. The slides were then incubated in a hybridizer (Hybridizer for in situ hybridization; S2450, Dako, Glostrup, Denmark) for denaturation at $75^{\circ} \mathrm{C}$ for 10 minutes and hybridization at $37^{\circ} \mathrm{C}$ for approximately 18 hours. Posthybridization washes were performed in urea/ $0.1 \times \mathrm{SSC}$ for 30 minutes at $45^{\circ} \mathrm{C}$ and in $2 \times \mathrm{SSC}$ for 2 minutes at room temperature. The slides were dehydrated in serial ethanol solutions, after which $15 \mu \mathrm{L}$ of mounting medium containing 4',6'-diamidino-2phenylindole (DAPI) was applied, and the tissue area was then coverslipped.

The criteria proposed by Jiang et al. ${ }^{13}$ were used to establish whether the FISH results were evaluable. In each case, 30 non-overlapping, intact interphasic tumor nuclei identified by DAPI staining were evaluated, and the copy numbers of the EGFR gene (green signal) and CEN7 (red signal) in each nucleus were determined. Amplification was defined as an average copy number ratio (EGFR/ CEN7) of 2.0 or greater in all nuclei evaluated or when the EGFR signals formed a tight gene cluster.

TMA was constructed by using 73 cases of ameloblastoma; however, in this study, only 25 cases were suitable for FISH analyses. In addition, the EGFR and Ki67 immunoexpressions from another study of our group $^{12}$ have been associated with FISH results.

\section{Statistical analysis}

All statistical analyses were performed by using the SPSS software program, version 23.0 (SPSS Inc., Chicago, IL). Categorical variables were compared by using Pearson's $\chi^{2}$ test or Fisher's exact test, depending on the expected values found in the contingency table. In all statistical tests, the alpha error was set at $5 \%$.

\section{RESULTS}

The clinicopathologic data of the participants are summarized in Table I.

All analyzed cases presented disomy (Figure 1A), and no gene polysomy or amplification was found. In EGFR IHC analysis, 3 cases (12\%) were considered negative
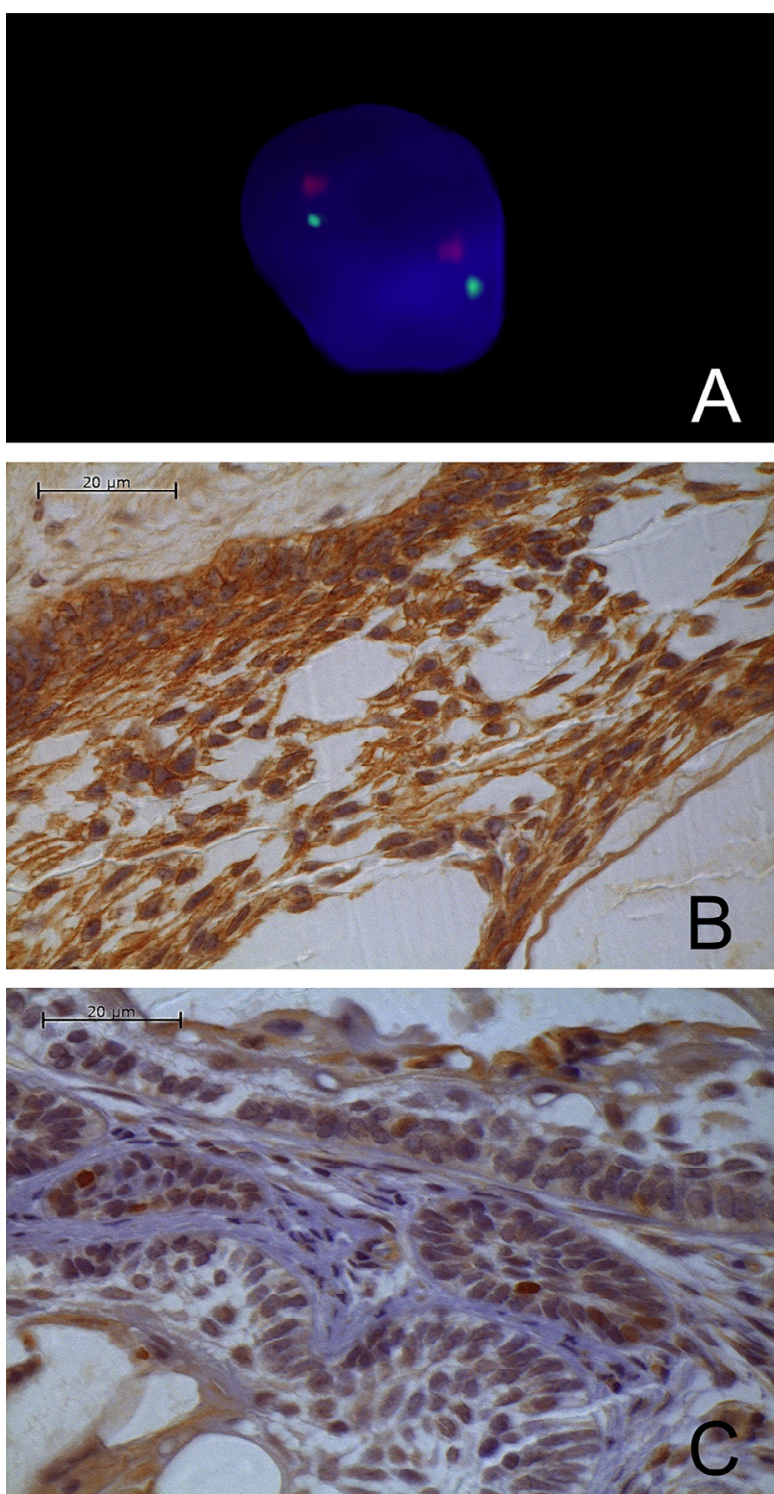

Fig. 1. A, EGFR disomy in nuclei of ameloblastoma cell (blue stained with DAPI), 2 signals of EGFR (green probe) and 2 signals of $C E N 7$ (red probe). $\mathbf{B}$, Ameloblastoma cells showing strong epidermal growth factor receptor (EGFR) membrane expression. C, Ameloblastoma cells showing expression of $\mathrm{Ki}$ 67 less than $10 \%$ of nuclear cells stained (Mayer's hematoxylin counterstain). 
Table I. Clinicopathologic features, EGFR status, and Ki-67 label of patients with ameloblastoma

\begin{tabular}{|c|c|c|c|c|c|c|c|c|c|c|c|}
\hline & Age (y) & Gender & Race & Location & $\begin{array}{l}\text { Radiographic } \\
\text { features }\end{array}$ & Histology & Treatment & EGFR FISH & $\begin{array}{c}\text { EGFR } \\
\text { expression }\end{array}$ & $K i-67$ & Relapse \\
\hline 1 & 21 & $\mathrm{~F}$ & White & Mandible & Unilocular & Follicular & Conservative & $\mathrm{D}$ & 2 & Low & Yes \\
\hline 2 & 40 & M & White & Mandible & Unilocular & Follicular & Aggressive & $\mathrm{D}$ & 2 & Low & No \\
\hline 3 & 35 & $\mathrm{~F}$ & White & Mandible & Multilocular & Follicular & Conservative & $\mathrm{D}$ & 1 & Low & Yes \\
\hline 4 & 22 & M & White & Mandible & Multilocular & Plexiform & Conservative & $\mathrm{D}$ & 1 & Low & Yes \\
\hline 5 & 36 & $\mathrm{~F}$ & Other & Mandible & Multilocular & Plexiform & Aggressive & $\mathrm{D}$ & 2 & Low & No \\
\hline 6 & 52 & M & White & Mandible & Multilocular & Plexiform & Conservative & $\mathrm{D}$ & 2 & Low & No \\
\hline 7 & 17 & M & Other & Mandible & Unilocular & Plexiform & Conservative & $\mathrm{D}$ & 2 & Low & No \\
\hline 8 & 49 & M & Other & Mandible & Unilocular & Plexiform & Aggressive & $\mathrm{D}$ & 1 & Low & No \\
\hline 9 & 32 & $\mathrm{~F}$ & Other & Mandible & Multilocular & Follicular & Conservative & $\mathrm{D}$ & 1 & Low & No \\
\hline 10 & 19 & $\mathrm{~F}$ & White & Mandible & Unilocular & Plexiform & Conservative & $\mathrm{D}$ & 1 & Low & No \\
\hline 11 & 12 & M & White & Mandible & Unilocular & Plexiform & Conservative & $\mathrm{D}$ & 1 & Low & No \\
\hline 12 & 35 & $\mathrm{~F}$ & Other & Mandible & Multilocular & Follicular & Conservative & $\mathrm{D}$ & 1 & Low & Yes \\
\hline 13 & 25 & M & Other & Mandible & Unilocular & Plexiform & Conservative & $\mathrm{D}$ & 1 & Low & No \\
\hline 14 & 17 & $\mathrm{~F}$ & White & Mandible & Multilocular & Plexiform & Conservative & $\mathrm{D}$ & 0 & Low & Yes \\
\hline 15 & 64 & M & White & Mandible & Multilocular & Follicular & Aggressive & $\mathrm{D}$ & 1 & Low & No \\
\hline 16 & 28 & $\mathrm{~F}$ & White & Mandible & Unilocular & Follicular & Aggressive & $\mathrm{D}$ & 1 & Low & Yes \\
\hline 17 & 46 & M & White & Maxilla & Multilocular & Plexiform & Conservative & $\mathrm{D}$ & 0 & Low & No \\
\hline 18 & 59 & M & White & Mandible & Unilocular & Plexiform & Conservative & $\mathrm{D}$ & 0 & Low & No \\
\hline 19 & 12 & $\mathrm{~F}$ & White & Mandible & Unilocular & Plexiform & Conservative & $\mathrm{D}$ & 2 & Low & No \\
\hline 20 & 27 & $\mathrm{~F}$ & White & Mandible & Unilocular & Plexiform & Conservative & $\mathrm{D}$ & 2 & Low & No \\
\hline 21 & 78 & $\mathrm{~F}$ & White & Maxilla & Unilocular & Plexiform & Conservative & $\mathrm{D}$ & 1 & Low & No \\
\hline 22 & 18 & M & White & Mandible & Unilocular & Plexiform & Conservative & $\mathrm{D}$ & 2 & Low & No \\
\hline 23 & 23 & $\mathrm{~F}$ & White & Mandible & Unilocular & Plexiform & Conservative & $\mathrm{D}$ & 1 & Low & No \\
\hline 24 & 24 & $\mathrm{~F}$ & Other & Mandible & Multilocular & Plexiform & Conservative & $\mathrm{D}$ & 2 & Low & No \\
\hline 25 & 30 & $\mathrm{~F}$ & Other & Mandible & Multilocular & Plexiform & Aggressive & $\mathrm{D}$ & 1 & Low & Yes \\
\hline
\end{tabular}

0 , negative; 1 , underexpression; 2, overexpression; $D$, disomy; EGFR, epidermal growth factor receptor; $F$, female; FISH, fluorescence in situ hybridization; low, $<10 \% ; M$, male.

and $22(88 \%)$ were positive, of which $13(52 \%)$ were weak, and 9 (36\%) were strong (Figure 1B). In Ki67 IHC analysis, all samples presented less than $10 \%$ of positivity (Figure 1C). No statistically significant association was observed between Ki67 or EGFR expressions and the clinicopathologic features and recurrence $(P>.05)$.

\section{DISCUSSION}

Ameloblastoma, the most common odontogenic neoplasm (excluding odontomas), is characterized by a tendency toward local infiltration of bone and soft tissue and recurrence. ${ }^{1}$ In the present study, FISH analysis revealed none of our samples to have gene amplification or polysomy, a result that is supported by the molecular study by Rotellini et al., ${ }^{14}$ who did not find EGFR gene alterations through FISH or gene sequencing in metastasizing ameloblastoma. Cells of pericoronal follicles that express EGFR respond to proliferative stimuli, exercising an important role in the pathogenesis of odontogenic lesions. ${ }^{15,16}$

In ameloblastoma, EGFR immunopositivity is reported in about $30 \%$ to $100 \%$ of cases. ${ }^{3,13,17-20}$ However, EGFR overexpression is reported in only about $9 \%$ to $16 \%$ of cases. ${ }^{3,18,19}$ A previous study by our group showed an EGFR immunopositivity of $77.1 \%$, with a strong positivity in $22(30.1 \%)$ cases. $^{12}$ The discrepancy in IHC results may have been caused by the use of different types of antibody clones and the criteria adopted for the IHC analysis, such as EGFR staining at the membrane only, cytoplasm only, or membrane and cytoplasm together. In addition, intratumor molecular heterogeneity ${ }^{21}$ can influence EGFR expression mainly in paraffin-embedded blocks. IHC and FISH can be used on TMA samples, with minimal changes to standard protocols. However, antigen retrieval techniques or enzymatic digestion, such as deproteination for FISH, may cause tissue detachment from the TMA slide and loss of the sample. ${ }^{22}$ Another difficulty was in standardization of the FISH protocol for ameloblastoma samples because a large number of samples did not present positivity even when standard protocols were used.

EGFR overexpression in ameloblastoma is related to the reactive increase of matrix metalloproteinase (MMP) secretion, and the signals generated by this molecular network are transduced by the ERK1/2 pathway, contributing to the tumor's aggressive behavior. ${ }^{23}$ da Rosa et al. ${ }^{24}$ used a primary cell line from human ameloblastoma samples transduced with human papillomavirus type 16 and suggested an interplay between the MMPs and EGFR in regulating ameloblastoma biology..$^{23}$

In this study, no association was found between EGFR amplification and protein overexpression. Some events can contribute to EGFR expression, regardless of EGFR amplification. EGFR can be overproduced at the level 
of transcription, which could be activated through tumorderived p53 mutants (p53-143 A, p53-175 H, p53-248 $\mathrm{W}, \mathrm{p} 53-273 \mathrm{H}$, and p53-281 G), even in the absence of gene amplification. ${ }^{25,26}$ Additionally, the inhibition of protein tyrosine phosphatases spontaneously activates EGFR in the absence of the ligand by EGF binding, and when EGFR is overexpressed, the phosphorylation levels of EGFR may exceed the capacity of the phosphatases, resulting in the enhanced activation of EGFR. ${ }^{26}$

Previous studies have recommended the use of antiEGFR agents to treat ameloblastoma. ${ }^{3,19,27}$ However, antiEGFR therapy may not be effective in view of the low rate of EGFR membrane immunostaining and in cases of nuclear EGFR expression. ${ }^{28}$ The most successful treatment for ameloblastoma is wide-excision surgery, including 1-cm margins in bone and a margin of the soft tissue plane; this approach greatly reduces the recurrence rate. Simple enucleation has a recurrence rate of $60 \%$ to $80 \% .^{1,29}$ In this study, recurrence was not associated with the type of treatment.

Despite EGFR expression, the Ki-67 proliferation index was found to be always low in this study and was not associated with recurrence or the histologic type of tumor. However, some authors have suggested the use of Ki67 as a marker to predict the prognosis and recurrence of ameloblastoma. ${ }^{13,19,30}$

\section{CONCLUSIONS}

The development and progression of ameloblastoma does not seem to occur as a result of EGFR amplification or polysomy. However, a high membrane expression of EGFR may play an important role in the pathogenesis of this disease, activating signaling pathways that may influence the proliferation, migration, and invasion of ameloblastoma cells.

We would like to thank José Ivanildo Neves for his technical assistance.

\section{REFERENCES}

1. El-Naggar AK, Chan JKC, Rubin Grandis J, Takata T, Slootweg PJ. International Agency for Research on Cancer. WHO Classification of Head and Neck Tumours. Lyon: IARC press; 2017.

2. Wright JM, Vered M. Update from the 4th edition of the World Health Organization classification of head and neck tumours: odontogenic and maxillofacial bone tumors. Head Neck Pathol. 2017; 11:68-77

3. Vered M, Shohat I, Buchner A. Epidermal growth factor receptor expression in ameloblastoma. Oral Oncol. 2003;39:138-143.

4. Fregnani ER, da Cruz Perez DE, de Almeida OP, Kowalski LP, Soares FA, de Abreu Alves F. Clinicopathological study and treatment outcomes of 121 cases of ameloblastomas. Int J Oral Maxillofac Surg. 2010;39:145-149.

5. Coussens L, Yang-Feng TL, Liao YC, et al. Tyrosine kinase receptor with extensive homology to EGF receptor shares chromosomal location with neu oncogene. Science. 1985;230: 1132-1139.
6. Gullick WJ, Downward J, Parker PJ, et al. The structure and function of the epidermal growth factor receptor studied by using antisynthetic peptide antibodies. Proc R Soc London Ser B Biol Sci. 1985;226:127-134

7. Xia W, Lau Y, Zhang H, et al. Combination of EGFR, HER-2 / neu, and HER-3 is a stronger predictor for the outcome of oral squamous cell carcinoma than any individual family members. Clin Cancer Res. 1999;5:4164-4174.

8. Cappuzzo F, Hirsch FR, Rossi E, et al. Epidermal growth factor receptor gene and protein and gefitinib sensitivity in non-smallcell lung cancer. J Natl Cancer Inst. 2005;97:643-655.

9. Steelman LS, Chappell WH, Abrams SL, et al. Roles of the Raf / MEK / ERK and PI3 K / PTEN / Akt / mTOR pathways in controlling growth and sensitivity to therapy-implications for cancer and aging. Aging (Albany NY). 2011;3:192-222.

10. Subramaniam D, He AR, Hwang J, et al. Irreversible multitargeted ErbB family inhibitors for therapy of lung and breast cancer. Curr Cancer Drug Targets. 2015;14:775-793.

11. Brown NA, Rolland D, McHugh JB, et al. Activating FGFR2RAS-BRAF mutations in ameloblastoma. Clin Cancer Res. 2014; 20:5517-5526.

12. Fregnani ER, Perez DE, Paes de Almeida O, et al. BRAF-V600 E expression correlates with ameloblastoma aggressiveness. Histopathology. 2017;70:473-484.

13. Jiang H, Bai X, Meng F, Zhang C, Zhang X. Evaluation of chromosome 17 polysomy in breast cancer by FISH analysis of whole nuclei, and its clinicopathological significance. Oncol Lett. 2014; 7:1954-1958.

14. Rotellini M, Maggiore G, Trovati M, Saraceno MS, Franchi A. Metastasizing maxillary ameloblastoma: report of a case with molecular characterization. J Oral Maxillofac Res. 2016;7:e5.

15. da Silva Baumgart C, da Silva Lauxen I, Filho MSA, de Quadros OF. Epidermal growth factor receptor distribution in pericoronal follicles: relationship with the origin of odontogenic cysts and tumors. Oral Surg Oral Med Oral Pathol Oral Radiol Endod. 2007; 103:240-245

16. de Oliveira MG, da Silva Lauxen I, Chaves ACM, Rados PV, Filho MSA. Odontogenic epithelium: immunolabeling of Ki-67, EGFR and Survivin in pericoronal follicles, dentigerous cysts and keratocystic odontogenic tumors. Head Neck Pathol. 2011;5:17.

17. Li TJ, Browne RM, Matthews JB. Expression of epidermal growth factor receptors by odontogenic jaw cysts. Virchows Arch A Pathol Anat Histopathol. 1993;423:137-144.

18. Nouri A, Cannell H, Onguti M, Tezabwala B, Oliver R. The possible relevance of the expression of MHC antigens and of EGF receptor in aggressive oral tumours. Int J Oncol. 1997;10:12171222.

19. Abdel-Aziz A, Amin MM. EGFR, CD10 and proliferation marker Ki67 expression in ameloblastoma: possible role in local recurrence. Diagn Pathol. 2012;7:14

20. Razavi SM, Torabinia N, Mohajeri MR, Shahriyary S, Ghalegolab $\mathrm{S}$, Nouri S. Expression of Bcl-2 and epithelial growth factor receptor proteins in keratocystic odontogenic tumor in comparison with dentigerous cyst and ameloblastoma. Dent Res J (Isfahan). 2015;12:342-347.

21. Gomes CC, Diniz MG, Gomez RS. Progress towards personalized medicine for ameloblastoma. J Pathol. 2014;232:488491

22. Voduc D, Kenney C, Nielsen TO. Tissue microarrays in clinical oncology. Semin Radiat Oncol. 2008;18:89-97.

23. Siqueira AS, Carvalho MRD, Monteiro ACD, Freitas VM, Jaeger RG, Pinheiro JJ. Matrix metalloproteinases, TIMPs and growth factors regulating ameloblastoma behaviour. Histopathology. 2010; $57: 128-137$ 
24. da Rosa MRP, Falcão AS, Fuzii HT, et al. EGFR signaling downstream of EGF regulates migration, invasion, and MMP secretion of immortalized cells derived from human ameloblastoma. Tumor Biol. 2014;35:11107-11120.

25. Ludes-Meyers JH, Subler MA, Shivakumar CV, et al. Transcriptional activation of the human epidermal growth factor receptor promoter by human p53. Mol Cell Biol. 1996;16:60096019.

26. Purba E, Saita E, Maruyama I. Activation of the EGF receptor by ligand binding and oncogenic mutations: the "rotation model". Cells. 2017;6:13.

27. Kurppa KJ, Catón J, Morgan PR, et al. High frequency of BRAF V600 E mutations in ameloblastoma. J Pathol. 2014;232:492498.

28. Pereira NB, De Melo do Carmo AC, Diniz MG, Gomez RS, Gomes DA, Gomes CC. Nuclear localization of epidermal growth factor receptor (EGFR) in ameloblastomas. Oncotarget. 2015;6:96799685 .
29. Pogrel MA, Montes DM. Is there a role for enucleation in the management of ameloblastoma? Int J Oral Maxillofac Surg. 2009;38: 807-812.

30. Olimid DA, Florescu AM, Cernea D, et al. The evaluation of p16 and Ki67 immunoexpression in ameloblastomas. Rom J Morphol Embryol. 2014;55:363-367.

\section{Reprint requests:}

Estela Kaminagakura, DDS, PhD

Department of Bioscience and Oral Diagnosis

Institute of Science and Technology

Universidade Estadual Paulista

Av. Eng. Francisco José Longo 777

São José dos Campos, 12245-000

Brazil

estela@ict.unesp.br 